\title{
PENGARUH GAYA KEPEMIMPINAN TERHADAP ETOS KERJA KARYAWAN PADA PT. PILAR ADHI PRATAMA
}

\author{
Oleh: \\ Rismayanti ${ }^{1}$ \\ Mohammad Ramadona ${ }^{2}$ \\ Program Studi Pendidikan Ekonomi \\ Fakultas Ilmu Pendidikan dan Pengetahuan Sosial \\ Universitas Indraprasta PGRI \\ Email: \\ Mohammadramadona1@gmail.com
}

\begin{abstract}
This research aims to determine the effect of leadership style on work ethic. One aspect that can improve company performance is a work ethic that drives employee morale. The level of the work ethic of employees is strongly influenced by a company's leadership style. A survey was conducted by administering questionnaires to 45 respondents as the saturated sample in PT. Pilar Adhi Pratama. The type of research is quantitative such as using questionnaires as data collection methods by than data analysis technique used is simple linear regression analysis. The results of the research show as data is a positive and significant influence between leadership style on employee work ethic at PT Pilar Adhi Pratama which is evidenced by the magnitude of $t_{\text {count }}>t_{\text {table }}$ with a 0.05 error level of 5.013> 2.015.
\end{abstract}

Keyword:Leadership Style, Quantitative Research, Work Ethos

\begin{abstract}
ABSTRAK
Penelitian ini akan menjajagi pengaruh gaya kepemimpinan terhadap etos kerja karyawan pada PT Pilar Adhi Pratama. Salah satu aspek yang dapatmempengaruhi kinerja perusahaan adalah etos kerja yang menggerakkan semangatkerjakayawan. Disisi lain, tinggi rendahnya etos kerja karyawan sangat dipengaruhi gaya kepemimpinan suatu perusahaan. Penelitian ini menggunakan jenis kuantitatif yang menggunakan sampeljenuh, berjumlah 45 responden, dengan menggunakan metode pengumpulan data berupa penyecaran kuesioner dan teknik analisis data yang digunakan adalah analisis regresi linier sederhana. Penelitian menunjukkan bahwa terdapat pengaruh yang positif dan signifikan antara gaya kepemimpinan terhadap etos kerja karyawan pada PT Pilar Adhi Pratama. Hal ini dibuktikan dengan besarnya $t_{\text {hitung }}>t_{\text {tabel }}$ dengan taraf kesalahan 0,05 yaitu $5,013>2,015$.
\end{abstract}

Kata Kunci: Etos Kerja, Gaya Kepemimpinan, Quantitative Research 


\section{A. PENDAHULUAN}

Sumber daya manusia merupakan faktor penting dalam perusahaan.Untuk menciptakan manajemen yang efektif, baiknya perusahaan memiliki sumber daya manusia yang berpengetahuan dan berketerampilan tinggi serta upaya untuk mengelola perusahaan seoptimal mungkin sehingga etos kerja karyawan meningkat. Etos kerja memiliki nilai-nilai semangat kerja, kecerdasan, kejujuran, loyalitas, dan aktualisasi diri. (Kinicki \& Williams, 2011, hal. 89) dalam bukunya mengatakan bahwa etos kerja memberikan pengaruh kepada seorang individu dalam perilakunya terhadap pekerjaan. sumber daya manusia yang memiliki etos kerja positif akan memiliki sebuah pandangan hidup yang positif, ia merupakan pribadi yang efisien, loyal, dan kreatif saat merasakan bahwa pekerjaan yang dilakukan memiliki nilai.

Etos kerja merupakan dasar perilaku yang paling utama mengenai pandangan benar atau salah. Menurut (Noe, et al., 2011, hal. 15) etos yaitu sebuah sikap moral mendasar dari seseorang yang memengaruhi sikapnya terhadap apa yang sedang dilakukannya, maka dapat disimpulkan bahwa etos kerja adalah sikap moral yang dimiliki seseorang dalam menjalani pekerjaannya. Setiap individu sebenarnya memiliki etos yang melekat, yang membedakan adalah bagaimana kualitas etos tersebut. Jika etos kerja yang dimiliki negatif maka kemungkinannya adalah kinerja yang diberikan oleh individu tidak akan maksimal karena ketidakpedulian terhadap perannya dalam proses pencapaian tujuan perusahaan. Sebaliknya karyawan dengan etos kerja yang positif akan menyadari pentingnya memberikan kinerja dan perilaku yang maksimal demi perusahaan.

Etos kerja dikembangkan melalui proses penyampaian dan pemindahan nilai moral perusahaan yang paling dasar. Nilai moral ini terangkum sepenuhnya dalam visi, misi dan tujuan yang telah ditetapkan perusahaan sebelumnya, dimana dalam prosesini kepemimpinan memegang perananyang penting. Hal ini dikarenakan pemimpin merupakan pihak yang berhubungan langsung dengan para karyawan sehingga karyawan akan melihat pemimpinnya tersebut sebagai perwakilan dari karyawan dalam proses keseluruhan perusahaan menilai dan memperlakukan para karyawannya. Jika pemimpin mampu melakukan proses ini dengan baik maka karyawan akan semakin percaya dan mudah dipengaruhi.

Pemimpin (leader)adalah orang yang menjalankan kepemimpinan (leadership). Kepemimpinan merupakan proses memengaruhi orang lain agar orang yang dipengaruhi mau mengikuti keinginan dari orang yang memengaruhi.

Gaya kepemimpinan merupakan norma perilaku yang digunakan seseorang saat mencoba memengaruhi orang lain. Gaya kepemimpinan seseorang identik dengan tipe kepemimpinan orang yang bersangkutan, yaitu cara yang disenangi

dan digunakan oleh seseorang sebagai wadah untuk menjalankan kepemimpinannya.

Permasalahan yang muncul terkait dengan kinerja seorang karyawan yang sering terjadi, seperti karyawan tidak bertanggung jawab dalam melaksanakan tugas yang diberikan, karyawan kurang aktif dalam menyelesaikan pekerjaan, 
karyawan bekerja menunggu perintah dari pimpinan, karyawan pasif dalam mengikuti pelatihan yang diadakan perusahaan, kerja sama dan komunikasi yang kurang baik antar sesama karyawan maupun terhadap pimpinan, sangat menentukan kemajuan kinerja dalam mencapai tujuan organisasi. Hal yang bisa mendasari permasalahan diatas bisa disebabkan oleh banyak faktor, diantaranya adalah gaya kepemimpinan dan etos kerja.

PT Pilar Adhi Pratama adalah perusahaandi bidang jasa konstruksi yang tentunya membutuhkan karyawan dengan etos kerja yang positif. Setiap karyawan harus memiliki etos kerja yang baik, sebab tanpa adanya etos kerja yang positif maka pekerjaan yang dilakukan oleh karyawan akan terganggu dan tidak maksimal.

Sukses atau tidaknya sebuah perusahaan ditentukan oleh kepemimpinan yang dibentuknya.Berdasarkan penelitian yang dilakukan, ditemukan karakteristik gaya kepemimpinan di PT Pilar Adhi Pratama mampu mendorong semangat karyawan untuk bekerjasama dalam tim dan mendengarkan keluhan dari persoalan yang berada di seputar lingkungan karyawannya. Sebagai perusahaan jasa, target dan waktu merupakan hal penting dalam tolok ukur kinerja perusahaan secara keseluruhan. Sehingga dalam setiap kali perusahaan berupaya untuk memperoleh peluang bisnis yang ada, pimpinan sering kali memberikan ruang aspirasi dan inspirasi bagi karyawan dalam pemenuhan target-target yang telah ditetapkan. Salah satu dampak dari pencapaian-pencapaian target yang ditetapkan perusahaan adalah seringkali karyawan menyelesaikan tugas yang didelegasikan dengan lembur. Namun begitu, seiring dengan over time kerja karyawan, perusahaan juga memperhatikan kesejahteraannya dalam bentuk insentif dari kelebihan waktu kerja tersebut.

\section{B. KAJIAN PUSTAKA}

\section{Kepemimpinan dan Gaya Kepemimpinan}

Menurut Koontz, et. al dalam (Bangun, 2012, hal. 339)mendefinisikan kepemimpinan sebagai pengaruh, seni, atau proses memengaruhi orang lain sehingga orang tersebut akan berusaha dalam pencapaian tujuan kelompok dengan kemauan dan antusias.

Griffin dalam (Sule \& Saefullah, 2017, hal. 255)membagi pengertian kepemimpinan menjadi dua konsep, yaitu sebagai proses dan sebagai atribut. Sebagai proses, kepemimpinan fokus kepada yang dilakukan oleh para pemimpin, yaitu proses dimana pemimpin menggunakan pengaruhnya untuk memperjelas tujuan perusahaan bagi para karyawan, memotivasi mereka untuk mencapai tujuan, serta membantu menciptakan suatu budaya produktif dalam perusahaan. Sedangkan sebagai atribut, kepemimpinan adalah kumpulan karakteristik yang harus dimiliki oleh seorang pemimpin. Oleh karena itu, pemimpin dapat diartikansebagai orang yang memiliki kemampuan untuk memengaruhi sikap orang lain tanpa menggunakan kekuatan, sehingga orang yang dipimpinnya menerima dirinya sebagai sosok yang layak memimpin mereka.

Menurut (Thoha, 2013, hal. 49)Gaya kepemimpinan adalah norma perilaku yang digunakan oleh seseorang saat orang tersebut mencoba memengaruhi 
perilaku orang lain seperti yang ia lihat. Maksudnya adalah norma perilaku pemimpin bisa memengaruhi perilaku karyawan yang dipimpinnya.

Mullins dalam (Noor, 2013, hal. 170) mendefinisikan bahwa gaya kepemimpinan sebagai "The way in which the functions of leadership are carried out, the way in which the manager typically behaves towards members of the group". Pengertian ini menyatakan bahwa gaya kepemimpinan adalah pengejawantahan tingkah laku dari seorang pemimpin, terkait kemampuannya dalam memimpin. Kemampuan seorang pemimpin dapat dibaca dengan tingkah lakunya sehari-hari.

\section{Macam-Macam Gaya Kepemimpinan}

Berbicara mengenai gaya kepemimpinan, (Robbins \& Judge, 2008, hal. 90)mengemukakan bahwa terdapat tiga macam gaya kepemimpinan, yaitu:

a) Gaya Kepemimpinan Transaksional

Kepemimpinan transaksional adalah pemimpin yang mengarahkan atau memotivasi karyawan pada arah tujuan yang telah ditetapkan dengan cara menegaskan peran dan tugas mereka.Indikator dari gaya kepemimpinan ini adalah:

(1) Penghargaan bersyarat: menjalankan pertukaran kontraktual antara penghargaan dan usaha, menjanjikan penghargaan untuk kinerja yang baik, dan mengakui pencapaian yang didapatkan.

(2) Manajemen dengan pengecualian (aktif): mengamati dan mencari distorsi dari aturan-aturan dan standar, serta melakukan tindakan perbaikan.

(3) Manajemen dengan pengecualian (pasif): dilakukan jika standar tidak tercapai.

(4) Lassez faire: melepaskan tanggung jawab dan menghindari pengambilan keputusan.

b) Gaya Kepemimpinan Transformasional

Kepemimpinan transformasional adalah pemimpin yang mengilhami karyawan untuk mengesampingkan kepentingan pribadi dan memiliki kemampuan memengaruhi yang mengagumkan. Kepemimpinan ini lebih baik dari pada kepemimpinan transaksional dan menghasilkan tingkat usaha dan kinerja karyawan melampaui target jika pendekatan transaksional ini diterapkan. Disaat seorang pemimpin transaksional yang baik tidak memiliki sifat-sifat transformasional, maka pemimpin tersebut adalah pemimpin yang biasa-biasa saja. Indikator dari gaya kepemimpinan ini adalah:

(1) Pengaruh yang ideal: memberikan visi dan misi, menumbuhkan kebanggaan, serta mendapatkan penghormatan dan kepercayaan.

(2) Motivasi yang inspirasional: mengkomunikasikan harapan yang tinggi, menggunakan simbol untuk berkonsentrasi pada usaha dan menyatakan tujuan utama secara sederhana.

(3) Stimulasi intelektual: meningkatkan kecerdasan, rasionalitas dan penyelesaian masalah yang akurat. 
(4) Pertimbangan yang bersifat individual: memberikan perhatian pribadi, memperlakukan masing-masing karyawan secara individual, serta melatih dan memberikan saran.

c) Gaya Kepemimpinan Laissez faire

Kepemimpinan laissez faire dijalankan dengan memberikan kebebasan penuh pada karyawan dalam mengambil keputusan dan melakukan kegiatan menurut keinginan dan kepentingan masing-masing baik secara individu maupun kelompok kecil. Laissez faire adalah gaya kepemimpinan yang paling pasif dan merupakan perilaku pemimpin yang paling tidak efektif.Indikator dari gaya kepemimpinan ini adalah:

(1) Tidak ada ikatan: melakukan pekerjaan dengan semaunya.

(2) Memberikan reaksi apabila ada masalah atau ikut campur jika adanya masalah di dalam perusahaan.

(3) Tidak disiplin (selalu terlambat dalam menyelesaikan pekerjaan).

(4) Tidak bertanggung jawab artinya menunda pekerjaan dan sering mengabaikan pekerjaan.

\section{Model Gaya Kepemimpinan}

\section{1) Model Kepemimpinan Situasional}

Paul Hersey dan Kenneth H Blanchard dikutip oleh (Sule \& Saefullah, 2017, hal. 264) membuat suatu model kepemimpinan situasional (situational leadership model). Model ini menyatakan bahwa para pemimpin perlu menyelaraskan gaya kepemimpinan mereka sebagai reaksi terhadap berbagai karakter dari karyawannya seperti harapan pekerja, pengalaman, keahlian dan kesanggupan dalam menerima tanggung jawab. Gaya kepemimpinan dibagi menjadi empat kuadran menurut situasi yang dihadapi dikaitkan dengan tinggi rendahnya kecenderungan kepada pekerjaan (task behavior) dan tinggi rendahnya kecenderungan kepada orang-orang (relationship behavior). Empat kuadran tersebut adalah:

a) High task and low relationship, kondisi yang dihadapi adalah adanya tuntutan pekerjaan yang tinggi dan rendahnya relasi. Maka pemimpin yang bertujuan pada pekerjaan yang tinggi lebih dibutuhkan, terkadang cenderung untuk sedikit otoriter, karena pada situasi ini pekerjaan lebih penting untuk dikerjakan daripada membangun relasi. Pemimpin harus memberikan panduan yang jelas kepada karyawan agar pekerjaan segera dilakukan. Gaya kepemimpinan yang berorientasi pada relasi, laissez-faire management dan manajemen partisipatif kurang efektif untuk digunakan pada situasi ini.

b) High task and high relationship, situasi yang dihadapi membutuhkan perhatian yang tinggi terhadap pekerjaan dan karyawan, gaya kepemimpinan demokratis, bertujuan pada kemajuan dan perubahan sangat diperlukan. Selain pekerjaan dapat dibereskan, pemimpin dalam kondisi ini berhadapan dengan tim kerja yang baik sehingga mereka tidak perlu diarahkan secara berlebihan untuk bekerja. Bahkan 
mungkin kepemimpinan yang bersifat laissez-faire sekalipun masih memungkinkan perusahaan ini tetap berjalan karena perusahaan memiliki satuan kerja yang baik dan memiliki semangat untuk berprestasi dalam pekerjaan. Peran pemimpin dalam kondisi ini tidak terlalu signifikan.

c) High relationship and low task, karyawan memiliki karakteristik kelompok kerja yang baik dan karyawan termotivasi dengan baik untuk berada dalam perusahaan, akan tetapi belum banyak diarahkan pada pekerjaan yang memberikan tantangan kepada mereka, sehingga orientasi pada pekerjaannya masih rendah. Menghadapi situasi seperti ini, pemimpin perlu untuk memberikan dukungan kepada orang-orang atau pekerja untuk melakukan apa yang terbaik dari pekerjaan mereka melalui pemberian motivasi akan pentingnya peningkatan prestasi. Pemimpin harus memerhatikan aspek relasi antar manusia sehingga pendekatan manajemen pastisipatif mungkin dapat dilakukan.

d) Low relationship and low task, tujuan terhadap pekerjaan dan orang rendah. Pemimpin harus bekerja keras untuk memberikan semangat kepada para pekerja sekaligus memberikan pedoman mengenai apa yang harus mereka lakukan. Jika menerapkan Laissez faire management style bisa berbahaya karena akan menyebabkan perusahaan tidak berjalan. Sama halnya jika pendekatan otoriter diterapkan belum tentu perusahaan berjalan dengan baik. Pemimpin pada kondisi ini berhadapan dengan orang-orang yang memiliki motivasi rendah, baik untuk berinteraksi sesama tim maupun untuk meraih prestasi dalam pekerjaan.

\section{2) Model LPC}

Fred Fiedler dalam(Sule \& Saefullah, 2017, hal. 266)menjelaskan model LPC bahwa gaya kepemimpinan sebaiknya digunakan berlainan dan tergantung kepada kecenderungan kondisi yang terjadi. LPC singkatan dari Least Preferred Coworker, artinya pemimpin perlu mengidentifikasi gaya kepemimpinan yang paling cocok untuk diimplementasikan dan disesuaikan dengan kondisi karyawan. Menurut Friedler, kiat pemahaman dari pendekatan situasional adalah tingkat kecenderungan pemimpin terhadap penilaian situasi karyawan. Friedler mengukur gaya kepemimpinan melalui angket. Angket tersebut berisi 16 pertanyaan yang mencoba menilai situasi karyawan. Friedler menyimpulkan ada tiga faktor kontingensi yang perlu dipertimbangkan dalam model LPC yaitu:

a) Relasi pemimpin-bawahan (leader-member relationship)

Relasi pemimpin-bawahan menggambarkan hubungan antara pemimpin dengan karyawan dilihat dari berbagai faktor seperti kepercayaan, penghargaan, kepercayaan diri. Jika kepercayaan antara pemimpin dengan karyawan baik, penghargaan dari kedua belah pihak baik dan seterusnya, maka hubungan pimpinan-bawahan digolongkan baik. Demikian pula sebaliknya. 
b) Struktur pekerjaan (task-structure)

Mengambarkan baik atau tidaknya seluruh rangkaian pekerjaan yang dilakukan dari mulai kejelasan tugas dan prosedur. Jika struktur pekerjaan ini tersedia dengan lengkap dan jelas, maka dikategorikan tinggi dan jika sebaliknya dikategorikan rendah.

c) Peran kekuasaan (power position).

Menggambarkan fungsi atau posisi kekuasaan pemimpin terhadap karyawannnya. Jika pemimpin memiliki fungsi yang kuat dalam memengaruhi dan mengarahkan karyawannya, maka faktor fungsi atau posisi kekuasaan ini dikategorikan kuat. Demikian pula sebaliknya, jika pemimpin kurang berfungsi dalam memengaruhi karyawannya, kebijakan dan keputusan diputuskan oleh orang lain, maka faktor fungsi atau posisi kekuasaan ini dikategorikan lemah.

\section{Dimensi dan Indikator Gaya Kepemimpinan}

Veitzhal Rivai (Rivai, 2014, hal. 53) mengemukan bahwa seorang pemimpin dalam mengimplementasikan kepemimpinannya harus mampu secara dewasa melaksanakan kedewasaan terhadap instansi atau organisasinya, kepemimpinan dibagi kedalam lima indikator dan dua belas dimensi, yaitu:

1. Kemampuan untuk membina kerjasama dan hubungan yang baik

a) Membina kerjasama dan hubungan baik dengan karyawan dalam pelaksanaan tugas yang menjadi tanggung jawab masing-masing

b) Kemampuan seorang pemimpin dalam memotivasi karyawannya

2. Kemampuan yang efektivitas

a) Mampu menyelesaikan tugas diluar kemampuan

b) Menyelesaikan tugas tepat waktu

c) Hadir tepat waktu

3. Kepemimpinan yang partisipatif

a) Pengambilan keputusan secara musyawarah

b) Dapat menyelesaikan masalah secara tepat

c) Mampu meniliti masalah yang terjadi pada pekerjaan

4. Kemampuan dalam mendelegasikan tugas atau waktu

a) Bersedia membawa kepentingan pribadi dan perusahaan kepada kepentingan yang lebih luas, yaitu mendahulukan kepentinganperusahaan dan menggunakan sisa waktu untuk keperluan pribadi

b) Mampu menyelesaikan tugas sesuai dengan target

5. Kemampuan dalam mendelegasikan tugas atau wewenang
a) Tanggung jawab seorang pemimpin dalam menyelesaikan tugas mana yang harus ditangani sendiri dan mana yang harus ditangani secara kelompok
b) Memberikan tuntunan dan pelatihan dalam pengambilan keputusan 


\section{Teori Tiga Dimensi Gaya Kepemimpinan}

Teori tiga dimensi kepemimpinan yang dikemukakan W.J. Reddin dalam (Suprihanto, 2014, hal. 69) mendasarkan teori gaya kepemimpinan atas tiga komponen penting, yaitu:

1. Orientasi Tugas (Task Orientation)

Model seorang pemimpin dapat dilihat dari kualitas keinginannya menyelesaikan pekerjaan. Dengan demikian, terdapat seorang pemimpin yang memiliki keinginan kuat untuk menyelesaikan pekerjaan yang dihadapi, tetapi terdapat pula pemimpin yang kurang kemauannya untuk menyelesaikan tugas.

2. Orientasi Hubungan (Relationship Orientation)

Model seorang pemimpin dapat juga dilihat dari tingkat perhatiannya terhadap hubungan dengan orang lain, baik hubungan dengan rekan maupun dengan karyawannya. Dengan demikian, ada pemimpin yang mempunyai hubungan erat dengan orang lain dan ada pula yang hubungannya sangat bersifat formal.

3. Orientasi Keefektifan (Effectiveness Orientation)

Komponen yang mengakibatkan seorang pemimpin yang satu berbeda dengan pemimpin lainnya adalah kemampuan untuk memperoleh produktivitas yang tinggi. Dengan demikian, ada seorang pemimpin yang sangat efektif dan ada pula yang tidak efektif

\section{Pengertian Etos Kerja}

Etos berasal dari kata Yunani, ethos, yang berarti karakter yang digunakan untuk menggambarkan keyakinan atau prinsip yang menjadi ciri sebuah komunitas. Menurut kamus besar bahasa Indonesia dalam (Ginting, 2016, hal. 2) mendefinisikan etos sebagai falsafah hidup yang khas dari suatu golongan.

Kerja dalam pengertian luas adalah semua bentuk upaya yang dilakukan manusia, baik dalam hal materi, intelektual dan fisik, ataupun hal yang berkaitan dengan dunia maupun akhirat. Menurut (Ginting, 2016, hal. 5) "kerja adalah melakukan aktivitas yang melibatkan usaha mental atau fisik yang dilakukan untuk mencapai hasil". Menurut Taslim Muhammad Yasin dalam (Bangun, 2012, hal. 105) etos adalah sikap fundamental terhadap diri mereka sendiri dan terhadap dunia mereka yang diimplementasikan dalam kehidupan, sehingga etos kerja adalah refleksi dari sikap hidup yang mendasar dalam menghadapi kerja. Kemudian, Soerjono Soekanto dalam (Bangun, 2012, hal. 107) menyebutkan bahwa etos adalah nilai-nilai dan ide-ide dari suatu kebudayaan, karakter umum suatu kebudayaan, sedangkan kerja merupakan suatu kegiatan atau aktivitas yang memiliki tujuan dan usaha yang dilakukan agar bermanfaat. Selain itu, Geertz dalam (Bangun, 2012, hal. 111) juga menjelaskan bahwa etos adalah sikap yang fundamental terhadap diri dan dunia yang dipancarkan hidup. Menurut (Hasibuan, 2010, hal. 41) "kerja adalah sejumlah kegiatan fisik dan mental seseorang untuk menggerjakan sesuatu pekerjaan." Kerja adalah suatu aktivitas, namun tidak 
semua kegiatan manusia sebagai pekerjaan, karena didalam arti pekerjaan terkandung dua aspek yang harus dimaknai secara nalar yaitu:

1. Aktivitas dilakukan karena ada dorongan untuk merealisasikan sesuatu sehingga berkembang rasa tanggung jawab yang besar untuk menghasilkan karya atau produk yang memiliki kualitas.

2. Apapun yang dilakukan karena kesengajaan, sesuatu yang direncanakan, karena itu terdapat didalamnya suatu semangat untuk mengerahkan segala potensi yang dimiliki sehingga apa yang dikerjakan benar-benar memberikan kepuasan dan manfaat.

Setelah membahas pengertian etos dan kerja, maka selanjutnya akan dibahas mengenai etos kerja. Berdasarkan kamus besar bahasa Indonesia, etos kerja adalah semangat kerja yang menjadi ciri khusus dan keyakinan seseorang atau suatu kelompok orang yang bekerja, yang berlandaskan etika dan perspektif kerja yang diyakini dan diwujudkan melalui tekad dan perilaku konkret didunia kerja.

Sinamo (Sinamo, 2011, hal. 56) menyatakan bahwa, "etos kerja adalah totalitas kepribadian diri serta cara memanifestasikan, memandang, meyakini, dan memberikan arti pada sesuatu, yang memotivasi diri untuk bertindak dan meraih kebaikan yang optimal". Maka seorang karyawan dengan etos kerja yang baik mampu membangun dan meningkatkan pengetahuannya. Setelah memiliki etos kerja dan pengetahuan yang baik, karyawan tersebut akan melaksanakan keterampilan yang telah dimiliki untuk membangun perusahaan menjadi lebih maju.

Menurut Gellerman dalam (Mailoor, 2015, hal. 10) "etos kerja merupakan sesuatu yang bersifat subjektif, tergantung dari perasaan seseorang sehubungan dengan pekerjaannya". Dikatakan juga bahwa etos kerja banyak dipengaruhi oleh norma yang dianut oleh seseorang dalam melakukan pekerjaanya, sedangkan nilai-nilai itu sendiri selalu berubah dan berkembang.

Gellerman dalam (Mailoor, 2015, hal. 11) mengemukakan bahwa etos kerja meliputi tiga bagian, yaitu:

1. Menyangkut kepuasan di luar pekerjaan, seperti: pendapat, rasa aman, kedudukan yang lebih tinggi dalam masyarakat.

2. Menyangkut kepada keputusan terhadap pekerjaan, seperti: minat terhadap pekerjaan, peluang untuk maju, wibawa dalam perusahaan dan kesempatan untuk berprestasi.

3. Menyangkut kepada kepuasan pribadi dan rasa bangga terhadap profesi yang dijalaninya.

\section{Faktor-Faktor yang Memengaruhi Etos Kerja}

Menurut Sinamo (Sinamo, 2011, hal. 51)secara umum faktor yang memengaruhi etos kerja dikelompokkan menjadi dua, yaitu:

1) Faktor Internal

Seseorang yang mempunyai etos kerja dapat dipengaruhi oleh motivasi yang berasal dari dalam diri atau faktor internal. Etos kerja adalah suatu pandangan dan sikap yang didasari oleh tolak ukur yang diyakini seseorang. 
Etos kerja ditentukan oleh kualitas pendidikan, keahlian, dan keterampilan yang dimiliki setiap individu untuk meningkatkan sumber daya manusia. Emosi negatif karyawan yang tidak dikelola dengan baik akan menjadi sumber masalah, dapat mengurangi upaya dan kerja keras, yang memengaruhi produktivitas, profitabilitas, kerja keras, kepuasan kerja, semangat kerja dan pada akhirnya akan mengurangi keberhasilan perusahaan untuk mencapai target.

2) Faktor eksternal

Budaya yang ada didalam masyarakat mampu memengaruhi etos kerja individu. Budaya tersebut meliputi, disiplin, sikap mental diyakini oleh masyarakat setempat. Masyarakat yang berorientasi untuk berkembang akan memiliki etos kerja yang tinggi. Sedangkan, masyarakat yang memiliki metode masyarakat konservatif atau yang biasa disebut kolot akan memiliki etos kerja yang rendah. Etos kerja akan dipengaruhi oleh lingkungan kerja yang mampu meningkatkan kinerja karyawan. Lingkungan kerja dipengaruhi oleh fasilitas kerja, gaji atau tunjangan,dan hubungan kerja. Hubungan kerja antara karyawan satu dengan yang lainnya dapat meningkatkan keproduktifan kerja ketika karyawan mampu menghadapi pekerjaannya dan juga ketenangan psikologis yang ditimbulkan dari hubungan kerja tersebut.

\section{Karakteristik Etos Kerja}

Menurut Sinamo (Sinamo, 2011, hal. 54) ada tiga karakteristik untuk menciptakan etos kerja karyawan yang bersinergi satu dengan yang lainnya secara utuh, yaitu:

1) Keahlian interpersonal

Keahlian yang dimiliki oleh karyawan yang berkaitan dengan hubungan antar karyawan di lingkungan kerja. Keahlian interpersonal meliputi karakteristik pribadi yang dapat memberikan fasilitasi agar terbentuk hubungan interpersonal yang baik dan memberikan kontribusi dalam kinerja yang baik.

2) Inisiatif

Perilaku yang dimiliki oleh karyawan yang dapat memfasilitasi dirinya agar termotivasi untuk lebih meningkatkan kinerjanya dan tidak langsung merasa puas dengan kualitas kerja yang biasa. Sifat karyawan seperti ini dapat digambarkan seperti cerdik, produktif, antusias, teliti.

3) Dapat diandalkan

Perilaku karyawan yang berhubungan langsung dengan adanya keinginan terhadap hasil kerja yang memuaskan, berdasarkan fungsi kerja yang diharapkan perusahaan. Etos kerja yang tinggi seharusnya dimiliki oleh seluruh karyawan karena perusahaan sangat memerlukan kerja keras dan komitmen yang tinggi dari setiap karyawan, jika tidak maka perusahaaan akan sulitberkembang. 
Agar perusahaan semakin maju, perusahaan perlu melibatkan karyawan untuk meningkatkan mutu kinerjanya, untuk itu setiap karyawan hendaknya memiliki etos kerja yangtinggi.

Dengan demikian, etos kerja merupakan kegiatan yang dilakukan oleh setiap karyawan. Untuk meningkatkan mutu kinerja karyawan diperlukan semangat kerja yang tinggi terutama kerja keras dan tanggung jawab untuk menjalankan pekerjaan.

\section{METODE PENELITIAN}

Penelitian ini dilaksanakan di PT Pilar Adhi Pratama yang berlokasi di Gedung Graha Arsa, Jl. Siaga Raya No.31 RT.05 RW.05, Pejaten Barat, Pasar Minggu, Jakarta Selatan pada bulan Februari hingga Juli 2019.

Sifat penelitian ini adalah kuantitatif deskriptif dengan teknik pengumpulan data melalui survey dan studi literatur. Variabel yang diteliti adalah variabel $\mathrm{X}$ (Gaya Kepemimpinan) sebagai variabel independen dan variabel Y (Etos Kerja) sebagai variabel dependen. Teknik analisis data yang dilakukan adalah dengan menggunakan rumus statistik, yaitu menghitung dan menguji validitas dan reabilitas data, koefisien korelasi Product Moment, regresi sederhana, uji hipotesis statistik dengan menggunakan T-Student untuk membuktikan hipotesis mengenai ada atau tidaknya pengaruh antara gaya kepemimpinan terhadap Etos Kerja. Populasi yang diteliti adalah karyawan di PT Pilar Adhi Pratama sejumlah 46 orang dengan menggunakan sampel jenuh. Metode penghimpunan data yang dilakukan melalui wawancara dan studi literatur.

\section{HASIL DAN PEMBAHASAN}

\section{Hasil Penelitian}

\section{Analisis Uji Validitas}

Instrumen yang digunakan dalam penelitian ini diperoleh melalui pengisian instrumen penelitian berupa angket yang berisi 25 butir pernyataan yang berkaitan dengan instrumen variabel $X$ (gaya kepemimpinan) dan 25 butir pernyataan yang berkaitan dengan instrumen variabel $\mathrm{Y}$ (etos kerja karyawan) dengan pilihan jawaban masing-masing item pernyataan sebanyak 5 item yaitu sangat setuju (SS), setuju (S), kurang setuju (KS), tidak setuju (TS), dan sangat tidak setuju (STS). Apabila nilai $r_{\text {hitung }}>r_{\text {tabel }}$ maka butir instrumen dianggap valid, tetapi sebaliknya apabila nilai $r_{\text {hitung }}<r_{\text {tabel }}$ maka butir instrumen dianggap tidak valid.Pengujian validitas diajukan kepada 46 responden dengan taraf signifikan $5 \%$ dengan nilai $r_{\text {tabel }}=0,2907$. Berikut tabel hasil uji validitas :

Dari hasil perhitungan, didapat 25 butir instrumen variabelX (gaya kepemimpinan) dinyatakan valid. Dan 25 butir instrumen variabel Y (etos kerja karyawan) dinyatakan valid. 


\section{Analisis Uji Reabilitas}

Pengujian alat pengumpulan data berikutnyaadalah pengujian reliabilitas.Pengujian reliabilitas dalam penelitian ini adalah menggunakan rumus Alpha Cronbach.

Tabel 4.5

Hasil Uji Reliabilitas

\begin{tabular}{ccc}
\hline Variabel & Hasil Uji Reliabilitas & Keterangan \\
\hline Gaya Kepemimpinan (X) & 0,835 & Reliabel \\
Etos Kerja Karyawan (Y) & 0,786 & Reliabel \\
\hline Sumber: Data primer diolah oleh peneliti, 2019
\end{tabular}

\section{Analisis Data}

\section{Pengujian Persyaratan Analisis}

Untuk menentukan apakah terdapat pengaruh gaya kepemimpinan terhadap etos kerja karyawan pada PT Pilar Adhi Pratama di Jakarta Selatan, maka diperlukan analisis data yang ditempuh dengan membuat tabel penolong dari data kedua variabel tersebut untuk memperoleh angka-angka yang diperlukan dalam perhitungan analisis regresi, analisis korelasi dan analisis koefisien determinasi.

\section{Menghitung Regresi Linier}

Analisis regresi dapat digunakan untuk mengukur hubungan fungsional atau hubungan sebab akibat antara gaya kepemimpinan(X) terhadap etos kerja karyawan (Y). Persamaannya sebagai berikut:

Keterangan :

$$
\mathrm{Y}=\mathrm{a}+\mathrm{bX}
$$

$\mathrm{Y}=$ Subjek dalam variabel dependen yang diprediksikan

$\mathrm{a} \quad=\quad$ Nilai $\mathrm{Y}$ bila $\mathrm{x}=0$ (harga konstan)

$\mathrm{b}=$ Angka arah atau koefisien regresi

$\mathrm{X}=$ Subjek pada variabel independen yang mempunyai nilai tertentu

Koefisien a dan $\mathrm{b}$ dapat dicari dengan menggunakan rumus sebagai berikut:

$$
\begin{gathered}
a=\frac{(\Sigma Y)\left(\Sigma X^{2}\right)-(\Sigma X)(\Sigma X Y)}{N\left(\Sigma X^{2}\right)-(\Sigma X)^{2}} \\
a=\frac{(4.174)(375.763)-(4.139)(374.747)}{46(375.763)-(4.139)^{2}}=46,89 \\
b=\frac{N(\Sigma X Y)-(\Sigma X)(\Sigma Y)}{N\left(\Sigma X^{2}\right)-(\Sigma X)^{2}} \\
=\frac{46(374.747)-(4.139)(4.147)}{46(375.763)-(4.139)^{2}}=0,48
\end{gathered}
$$


Dari perhitungan diatas, diperoleh nilai a sebesar 46,89 dan nilai b sebesar 0,48. Maka terbentuklah persamaan regresi linier sederhana $\mathrm{Y}$ atas $\mathrm{X}$ adalah:

$$
\begin{gathered}
\mathrm{Y}=\mathrm{a}+\mathrm{bX} \\
\mathrm{Y}=46,89+0,48 \mathrm{X}
\end{gathered}
$$

Dari perhitungan regresi diatas membuktikan bahwa terdapat pengaruh yang positif antara gaya kepemimpinan terhadap etos kerja karyawan pada PT Pilar Adhi Pratama. Setelah nilai a dan b ditemukan maka diperoleh persamaan regresi linier sederhana yaitu $Y=46,89+0,48 X$ artinya setiap perubahan nilai variabel $X$ maka akan diikuti dengan perubahan nilai $Y$. Jika $X$ bertambah 1 maka $Y$ bertambah sebesar 0,48 (pengaruh positif). Jadi setiap kenaikan variabel $\mathrm{X}$, makaakan meningkatkan variabel Y.

\section{a. Analisis Korelasi Sederhana (Korelasi Product Moment)}

Koefisien korelasi $\left(\mathrm{r}_{\mathrm{xy}}\right)$ digunakan untuk mengetahui seberapa kuat pengaruh variabel $\mathrm{X}$ (gaya kepemimpinan) terhadap variabel $\mathrm{Y}$ (etos kerja karyawan). Koefisien korelasi ( $\left.\mathrm{r}_{\mathrm{xy}}\right)$ dihitung menggunakan rumus product moment sebagai berikut:

$$
\begin{gathered}
r x y=\frac{N \sum X Y-\left(\sum X\right)\left(\sum Y\right)}{\sqrt{\left[N \sum X^{2}-\left(\sum X\right)^{2}\right]\left[N \sum Y^{2}-\left(\sum Y\right)^{2}\right]}} \\
r_{x y}=\frac{46(374.747)-(4.139)(4.147)}{\sqrt{\left[46(375.763)-(4.139)^{2}\right]\left[46(375.977)-(4.147)^{2}\right]}}=0,64
\end{gathered}
$$

Dari hasil koefisien korelasi diatas dapat dijelaskan seberapa kuat pengaruh antara variabel gaya kepemimpinan terhadap etos kerja karyawan pada PT Pilar Adhi Pratama. Jika hasil $r$ dinyatakan dengan sangat rendah atau rendah maka kesimpulannya adalah hubungan kedua variabel sangat rendah serta tidak ada pengaruh positif dan signifikan.Namun, jika hasil korelasi tersebut termasuk kategori kuat ataupun sangat kuat maka kesimpulan yang dapat diambil bahwa kedua variabel mempunyai pengaruh yang positif dan signifikan. Untuk mengetahui hal tersebut maka dapat dilihat dari tabel interval koefisien korelasi dibawah ini :

Tabel 4.7

Interprestasi Koefisien Korelasi

\begin{tabular}{cc}
\hline INTERVAL KOEFISIEN & TINGKAT HUBUNGAN \\
\hline $0,80-1,000$ & Sangat Kuat \\
$0,60-0,799$ & Kuat \\
$0,40-0,599$ & Cukup Kuat \\
$0,20-0,399$ & Rendah \\
$0,00-0,199$ & Sangat Rendah \\
\hline Sumber : (Riduwan, 2015, hal. 138)
\end{tabular}

Dari perhitungan diatas, diperoleh koefisien korelasi $\left(\mathrm{r}_{\mathrm{xy}}\right)=0,604$. Berdasarkan tabel pedoman interprestasi koefisien korelasi $r_{x y}=0,604$ berada 
pada interval 0,60-0,799 yang artinya bahwa pengaruh gaya kepemimpinan terhadap etos kerja karyawan pada PT Pilar Adhi Pratama pada level kuat.

Angka positif pada koefisien korelasi tersebut menunjukkan bahwa antara variabel gaya kepemimpinan (X) dengan variabel etos kerja karyawan (Y) memiliki hubungan yang searah. Dengan demikian, dapat diinterpretasikan bahwa semakin tinggi tingkat gaya kepemimpinan maka semakin tinggi pula etos kerja karyawannya.

\section{b. Analisis Koefisien Determinasi}

Perhitungan koefisien determinasi digunakan untuk mengetahui seberapa besar sumbangan variabel $\mathrm{X}$ (gaya kepemimpinan) terhadap variabel $\mathrm{Y}$ (etos kerja). Koefisien determinasi dapat ditentukan dengan rumus sebagai berikut:

$$
\begin{gathered}
\mathrm{KD}=\mathrm{r}^{2} \times 100 \% \\
=(0,604)^{2} \times 100 \%=36,48 \%
\end{gathered}
$$

Dari perhitungan diatas, diperoleh koefisien determinasi sebesar 36,48\%. Dapat disimpulkan bahwa pengaruh gaya kepemimpinan mempunyai kontribusi sebesar 36,48\% terhadap etoskerjakaryawan, sedangkan sisanya sebesar 63,52\% merupakan kontribusi yang dipengaruhi dari faktor lain.

c. Uji Hipotesis

Untuk menguji hipotesis yang diajukan dalam penelitian ini, dilakukan pengujian dengan menggunakan analisis uji-t dengan bentuk hipotesis sebagai berikut:

$H_{o}: \rho=0$ : artinya bahwa antara gaya kepemimpinan danetoskerjadi PT Pilar Adhi Pratamatidak mempunyai pengaruh yang signifikan $H_{a}: \rho \neq 0 \quad$ : artinya bahwa antara gaya kepemimpinan dan etos kerjadi PT Pilar Adhi Pratama terdapat pengaruh yang signifikan

Dalam uji-t diperoleh hasil penghitungan sebagai berikut:

$$
\begin{gathered}
t=\frac{r \sqrt{N-2}}{\sqrt{1-r^{2}}} \\
t=\frac{0,604 \sqrt{46-2}}{\sqrt{1-(0,604)^{2}}}=5,013
\end{gathered}
$$

Dari perhitungan diatas diperoleh nilai $\mathrm{t}_{\text {hitung }}$ sebesar $=5,013$. Untuk menentukan $\mathrm{t}_{\text {tabel, }}$, maka $\mathrm{t}_{\text {tabel }} \alpha=0,05$ dengan derajat kebebasan $(\mathrm{dk})=\mathrm{n}-2 . \mathrm{t}_{\text {tabel }} \alpha=0,05$ dengan derajat kebebasan $(\mathrm{dk})=46-2=44$ adalah 2,015Berdasarkan hasil perhitungan uji $\mathrm{t}_{\text {hitung }}$ dan besarnya $\mathrm{t}_{\text {tabel }}$ di atas, maka $\mathrm{t}_{\text {hitung }}>\mathrm{t}_{\text {tabel }}(5,013>2,015)$, sehingga $\mathrm{H}_{0}$ ditolak dan $\mathrm{H}_{\mathrm{a}}$ diterima artinya terdapat pengaruh yang signifikan antara gaya kepemimpinan terhadap etos kerja karyawan pada PT Pilar Adhi Pratama. 


\section{Pembahasan InterprestasiHasilPenelitian}

\section{Menghitung Regresi Linier}

Terdapat pengaruh yang signifikan antara gaya kepemimpinan terhadap etos kerja yang diberikan pihak perusahaan terhadap karyawannya di PT Pilar Adhi Pratama, yaitu sebesar $\mathrm{Y}=46,89+0,48 \mathrm{X}$

\section{Analisis Korelasi Sederhana (Korelasi Product Moment)}

Dari perhitungan korelasi ditemukan sebesar 0,604 terdapat hubungan yang positif antara gaya kepemimpinan terhadap etos kerja karyawan pada PT. Pilar Adhi Pratama.Berdasarkan tabel interval dapat juga dilihat bahwa pengaruh kedua variabel mempunyai kategori yang kuat. Jadi, dari kedua pedoman diatas terdapat pengaruh yang signifikan antara gaya kepemimpinan terhadap etos kerja karyawan pada PT. Pilar Adhi Pratama.

\section{Analisis Koefisien Determinasi}

Dalam perhitungan ini, ditemukan koefisien determinasinya (KD) $36,48 \%$ artinya pengaruh gaya kepemimpinan (X) terhadap etoskerjakaryawan (Y) padaPT Pilar Adhi Pratamasama dengan 36,48\% sedangkan sisanya63,52\% merupakan kontribusi yang dipengaruhi dari faktor lain yang tidak termasuk dalam penelitian ini.

\section{Uji Hipotesis (Uji-t)}

Dalam perhitungan ini dinyatakan bahwa $t_{\text {hitung }}$ lebih besar dari $t_{\text {tabel }}$ $(5,013>2,015)$ artinya bahwa terdapat pengaruh yang signifikan antara gaya kepemimpinan (X) terhadap etos kerja karyawan (Y) pada PT Pilar Adhi Pratama.

\section{E. SIMPULAN}

Berdasarkanhasilpenelitiantentangpengaruh gaya kepemimpinan terhadap etos kerja karyawan pada PT Pilar Adhi Pratama,disimpulkan sebagai berikut:

1. Persamaan regresi linear sederhana $Y=46,89+0,48 X$, karena koefisien regresi linier (b) bernilai positif yaitu 0,48 , menunjukkan bahwa terdapat hubungan antara variabel $\mathrm{X}$ (gaya kepemimpinan) dengan variabel $\mathrm{Y}$ (etos kerja karyawan).

2. Koefisien korelasi $\left(\mathrm{r}_{\mathrm{xy}}\right)=0,604$ menunjukkan hubungan yang kuat antara variabel X (gaya kepemimpinan) terhadap variabel Y (etos kerja karyawan). Angka positif pada koefisien korelasi tersebut menunjukkan bahwa antara variabel gaya kepemimpinan (X) dengan variabel etos kerja karyawan (Y) memiliki hubungan yang searah. Dengan demikian, dapat diinterpretasikan bahwa semakin tinggi tingkat gaya kepemimpinan yang diberikan oleh pimpinan perusahaan maka semakin tinggi pula etos kerja karyawannya.

3. Dalam perhitungan koefisien determinasi diperoleh KD sebesar $36,48 \%$. Hasil tersebut menunjukkan bahwa pengaruh gaya kepemimpinan mempunyai kontribusi sebesar $36,48 \%$ terhadap etos kerja karyawan 
sedangkan sisanya sebesar 63,52\% merupakan kontribusi yang dipengaruhi oleh faktor lain.

4. Hasil uji hipotesis dalam penelitian ini menunjukkan bahwa terdapat pengaruh yang positif dan signifikan antara gaya kepemimpinan terhadap etos kerja karyawan pada PT Pilar Adhi Pratama. Hal ini dibuktikan dengan besarnya $\mathrm{t}_{\text {hitung }}>\mathrm{t}_{\text {tabel }}$ dengan taraf kesalahan 0,05 yaitu5,013> 2,015. 


\section{DAFTAR PUSTAKA}

Bangun, W. (2012). Manajemen Sumber Daya Manusia. Jakarta, DKI Jakarta, Indonesia: Erlangga.

Ginting, D. (2016). Etos Kerja: Panduan Menjadi Karyawan Cerdas. Jakarta, DKI Jakarta, Indonesia: PT Elex Mekdia Komputindo.

Hasibuan, M. S. (2010). Manajemen Sumber Daya Manusia. Jakarta, DKI Jakarta, Indonesia: Bumi Aksara.

Kinicki, A., \& Williams, B. K. (2011). Management: A Practical Introduction (5 ed.). Jakarta, DKI Jakarta, Indonesia: Salemba Empat.

Mailoor, M. V. (2015). Pengaruh Etos Kerja Terhadap Kinerja Pegawai Pada PT. Pelabuhan Indonesia IV (Persero) Terminal Petikemas Bitung. Manado: Politeknik Negeri Manado.

Noe, Raymond, Hollenbeck, John, Gerhart, Barry, et al. (2011). Fundamentals of Human Resource Management (4 ed.). Jakarta, DKI Jakarta, Indonesia: Erlangga.

Noor, J. (2013). Penelitian Ilmu Manajemen: Tinjauan Filosofis dan Praktis (1 ed., Vol. 1). Jakarta, DKI Jakarta, Indonesia: Kencana.

Riduwan. (2015). Belajar Mudah Penelitian Untuk Guru, Karyawan dan Peneliti Pemula. Bandung, Jawa Barat, Indonesia: Alfabeta.

Rivai, V. (2014). Manajemen Sumber Daya Manusia Untuk Perusahaan (6 ed.). Depok, Jawa Barat, Indonesia: Raja Grafindo Persada.

Robbins, S. P., \& Judge. (2008). Perilaku Organisasi (2 ed.). Jakarta, DKI Jakarta, Indonesia: Salemba Empat.

Sinamo, J. (2011). Delapan Etos Kerja Profesional. Bogor, Jawa Barat, Indonesia: PT Grafika Mardi Yuana.

Sule, E. T., \& Saefullah, K. (2017). Pengantar Manajemen (1 ed., Vol. 10). Jakarta, DKI Jakarta, Indonesia: Kencana.

Suprihanto, J. (2014). Manajemen. Yogyakarta: Gadjah Mada University Press.

Thoha, M. (2013). Perilaku Organisasi Konsep Dasar dan Aplikasinya. Jakarta, DKI Jakarta, Indonesia: PT Raja Grafindo Persada. 